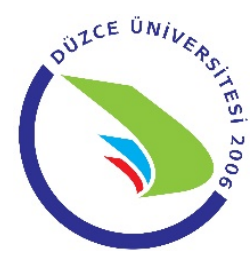

\title{
Bir Üniversite Hastanesinde Çalışan Yoğun Bakım Hemşirelerinin Karşılaştıkları Etik Sorunların Stres Düzeylerine Etkisi
}

\author{
Didem ÖNDAŞ AYBAR 國 ${ }^{1}$, Serap PARLAR KILIÇ ${ }^{2}$
}

ÖZ

Amaç: Tanımlayıcı nitelikteki bu araştırmanın amacı bir üniversite hastanesinde çalışan yoğun bakım hemşirelerinin karşılaştıkları etik sorunların hemşirelerin stres düzeylerine etkisini belirlemektir.

Gereç ve Yöntemler: Araştırmanın örneklemini bir üniversite hastanesinin yoğun bakım ünitelerinde (YBÜ) çalışan ve araştırmaya katılmayı kabul eden 144 hemşire oluşturmuş̧ur. Veriler; araştırmacılar tarafından literatür desteği ile hazırlanan tanıtıcı bilgi formu, Algılanan Stres Ölçeği ve Yoğun Bakım Hemşirelerinin Yaşadıkları Etik Sorunlar Formu ile toplanmıştır. Veriler Mann-Whitney U testi ile analiz edilmiştir.

Bulgular: Yoğun bakım ünitelerinde çalışan hemşirelerin yaş ortalaması 29,06 $\pm 4,02$, hemşirelerin yoğun bakım ünitesinde çalışma yılı ortalamas $4,39 \pm 3,48$ olup, hemşirelerin \%86,1'inin etik ile ilgili eğitim aldığ 1 ve çoğunluğunun $(\% 87,9)$ bu eğitimi mezun oldukları okullarında aldıkları saptanmıştır. Yoğun bakım ünitelerinde çalışan hemşirelerin karşılaştıkları etik sorunlar içerisinde en yüksek oranın "Mesleki hiyerarşide alt basamaklarda yer alanlara fazla iş

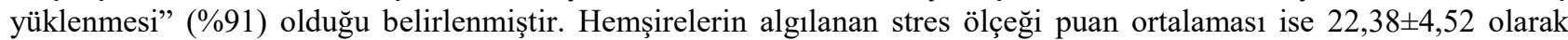
bulunmuş olup, sadece "Hekim tarafindan yerine getirilmesi gereken uygulamaların hemşirelere devredilmesi" etik sorunu ile karşılaşanların karşıllaşmayanlara göre algılanan stres düzeylerinin daha yüksek olduğu saptanmıştır $(p<0,05)$. Sonuç: $\mathrm{Bu}$ araştırmada yoğun bakım hemşirelerinin etik sorunlarla sıklıkla karşılaştıkları, bu sorunların çoğunluğunu orta düzeyde önemsedikleri ve etik sorunların hemşirelerin stres algısını etkilediği saptanmıştır. Hemşirelerin karşılaştıkları her etik durumu profesyonel bir şekilde ele alarak değerlendirmesi ve çözümler geliştirmesi yaşanabilecek stres faktörlerinin önlenmesinde önemlidir.

Anahtar Kelimeler: Etik; hemşire; stres; yoğun bakım üniteleri.

\section{The Effect on Their Stress Levels of Ethical Problems Faced by Intensive Care Nurses Working in a University Hospital}

\begin{abstract}
Aim: This descriptive study was conducted to determine the effect of ethical issues faced by intensive care nurses working in a university hospital on their stress levels.

Material and Methods: The sample of this study consisted of 144 nurses working in intensive care units (ICU) of a university hospital and agreeing to participate in the study. Data were collected using introductory information form prepared by the researcher with literature support, Perceived Stress Scale, and Ethical Problems Form for Intensive Care Nurses. Data were analyzed using Mann-Whitney U test.

Results: It was determined that age average of the intensive care nurses was $29.06 \pm 4.02$ years, their average duration of working in the intensive care unit was $4.39 \pm 3.48$ years. It was found that $86.1 \%$ of the nurses received ethics-related education and the majority (87.9\%) received this education in the schools they graduated from. Among the ethical issues faced by them, the highest rate was observed in "Laying too much burden on those at the bottom in the occupational hierarchy" (91\%). Their mean score of perceived stress scale was 22.38 \pm 4.52 . The perceived stress levels were higher in those encountering only with "Handing over practices supposed to be performed by physicians to nurses” ethical issue than those who did not $(\mathrm{p}<0.05)$.
\end{abstract}

\footnotetext{
1 Fırat Üniversitesi, Sağlık Bilimleri Enstitüsü, Hemşirelik AD, Elazığ, Türkiye

2 İnönü Üniversitesi, Hemşirelik Fakültesi, İç Hastalıkları Hemşireliği AD, Malatya, Türkiye sunulmuştur.

*Bu çalışma, 11-12 Eylül 2017 tarihleri arasında İzmir'de düzenlenen Uluslararası Hemşirelik Uygulamalarında Etik Kongresi'nde sözel bildiri olarak 
Conclusion: It was determined in this study that intensive care nurses frequently faced ethical issues and regarded majority of these problems at the moderate level and ethical issues affected their stress perception. It is important for nurses to address and assess professionally each ethical issue they encounter and to develop solutions in order to prevent possible stress factors.

Keywords: Ethics; nurse; stress; intensive care units.

\section{GÍRIS}

Yoğun bakım üniteleri (YBÜ) kritik hastaları destekleyerek onların iyileşmesini amaçlayan, hastaların 24 saat yaşamsal göstergelerinin izlendiği ve multidisipliner bir ekibin hizmet sunduğu klinikler olarak tanımlanmaktadır (1). YBÜ, hastalık veya travma sonucu yaşam fonksiyonları ileri derecede bozulmuş olan veya her an bozulma riski taşıyan hastalara yüksek teknolojiye sahip araç gereçler ile tedavi ve bakım hizmetlerinin ve yaşam desteklerinin sürdürüldüğü özel ünitelerdir (2).

Yoğun bakım ünitelerinin çok yönlü ve kompleks yapıları pek çok sorunu da beraberinde getirmektedir. Bu sorunlar, yoğun bakıma hasta kabulünden, uygulanan tedavinin sınırlarını belirlemeye ve yoğun bakımın maliyetlerine kadar uzanan geniş bir yelpazeyi kapsamaktadır. Yoğun bakım ünitelerinin değişken yapısı, ölümle yaşam çizgisinin başlangıcı veya bitişinin belirsizliği gibi nedenler etik sorunların yoğun bakım ünitesinde sıkça yaşanmasına yol açmaktadır (3). Bunun yanı sıra bilinç düzeyi değişikliği nedeni ile yoğun bakım ünitelerinde yatan hastalarla iletişim kurulamaması, teknoloji destekli hizmet sunumu, acil kararlar verme, acil müdahalede bulunma zorunluluğu ve bu hastaların sağlık sorunlarının ciddiyeti gibi nedenlerle de yoğun bakım ünitelerinde etik sorunlarla daha s1k karşılaşılmaktadır (4). Yoğun bakım ünitelerinde sağlık profesyonellerinin sıklıkla karşılaştığı, genellikle etik düşünmeyi ve etik karar vermeyi gerektiren en hassas konuların; tedavi kararları, bilgilendirilmiş onam alma, resüsitasyon uygulama, organ transplantasyonu, hastanın mahremiyet ve özerkliğinin korunması, tıbbi kaynakların adil paylaşımı, hastaların tanı ve tedavi süreçleri hakkında bilgilendirilmesi, terminal dönemdeki hastanın bakımı, hasta haklarının korunması ve ötanazi ile ilgili olduğu saptanmıştır (2).

Çağdaş rolleri arasında hasta savunuculuğu ön planda olan hemşirelerin, kritik hasta bakımı sırasında etik sorunlarla karşılaşması kaçınılmazdır (4). Yoğun bakım hemşirelerinin hastanın durumunda ortaya çıkan değişiklikleri ilk saptayan ve acil durumlarda ekip içinde hızlı karar alması gereken bir meslek üyesi olması sebebiyle, beklenmedik bir anda ortaya çıkan etik sorunlarla sıklıkla karşılaştığı belirtilmektedir (5). Ayrıca, yoğun bakım hemşireleri çalıştıkları hasta grubunun özelliği ve bu ünitelerde yapılan bakım ile ilgili müdahalelerin durumu gibi nedenlerden dolayı da etik sorunları daha sı yaşamaktadırlar (6). Park ve arkadaşları (7) YBÜ'lerinde çalıșan hemşirelerle yaptıkları çalışmalarında; hemşirelerin \%20,2'sinin etik sorunlarla karşı karşıya kaldıklarını saptamışlardır. Dikmen (6) hemşirelerin \%74'ünün yoğun bakımda çalıştıkları süre boyunca etik sorunlar yaşadıklarını, etik sorunlar yaşayanların \%62'sinin ise, yaşadıkları bu etik sorunları çözemediklerini bulmuştur. Yönt ve arkadaşları
(8) çalışmalarında; YBÜ'nde çalışan hemşirelerin yetki, yetersizlik, kaynak kullanımında adil olma, doğru karar verme ve bilgilendirme konularında etik sorunlar yaşadıklarını belirlemişlerdir. Yoğun bakım ünitelerinde çalışan hemşireler bu etik sorunlar ve ikilemler karşısında bakım ve tedavi ile ilgili uygulamaları sürdürmekten ve bunu sağlarken de hastaların yaşam kalitesini artırmaktan sorumludur (9).

YBÜ’leri sürekli acil durum beklentisi, yüksek teknoloji karmaşıklığı, hastaların genel sağlık durumundaki ani değişim takipleri nedeni ile stres düzeyi yüksek çalışma ortamları olarak kabul edilmektedir (10). Ayrıca YBÜ'lerinin etik ortamının ve yaşanan etik sorunların stres ve anksiyeteye neden olduğu belirtilmektedir (11). YBÜ'lerinde eşit etkiye/yarara sahip görünen iki seçenekten birine karar vermek durumunda kalınması ve bu karar vermeyi destekleyen bilginin ve kullanılacak kaynakların sınırlı olması, var olan durumu daha stresli ve zor hale getirmektedir. YBÜ’lerinde genellikle primer karar vericinin hekim olması, yoğun bakım hemşirelerinin karar verme sürecine katılımlarının sınırlı olması gibi durumlar da hemşirelerde stres ve anksiyetenin artmasına yol açmaktadır. Bunun yanı sıra etik sorunların farklı algılanması yanlış anlaşılma ve çatışmalara yol açmakta ve bu durum da ekip üyelerinde ciddi bir gerilim yaratmaktadır (4). Bu nedenle yoğun bakım ünitelerinde kritik hasta bakımı sırasında ortaya çıkan etik sorunların azaltılması, sağlıklı çözümler üretilmesi ve hemşirelerin yaşadığı stres düzeyinin azaltılmasına yönelik girişimlerin düzenlenmesi önemlidir. Ancak zamanın ve koşulların sınırlı olması nedeniyle bu çözüm arayışı zor ve zahmetli olabilmektedir (9). Tüm bu verilerle bu çalışmada yoğun bakım ünitelerinde çalışan hemşirelerin yaşadıkları etik sorunların hemşirelerin stres düzeylerine etkilerini belirlemek amaçlanmıştır.

\section{GEREÇ VE YÖNTEMLER \\ Araştırma Türü}

Tanımlayıcı nitelikte olan bu çalışma Temmuz 2017Ocak 2018 tarihleri arasında yürütülmüştür.

\section{Araștırma Evreni ve Örneklemi}

Araştırmanın evrenini Türkiye'nin bir ilinde bulunan üniversite hastanesindeki tüm yoğun bakım ünitelerinde çalışan 165 hemşire oluşturmuştur. Çalışmanın yapıldığı hastanenin yoğun bakım ünitelerinde çalışan hemşirelerden ulaşılan ve çalışmaya katılmayı kabul eden hemşireler ise araştırmanın örneklemini oluşturmuştur. Çalışmanın yapıldığı tarihler arasında izinli olan, çalışmaya katılmak istemeyen, doldurulmayan veya yarım bırakılan anketler ise çalışma dışı bırakılmıştır. Böylece belirtilen tarihler arasında bu hastanelerde çalışan ve araştırmaya katılmayı kabul eden 144 hemşire çalışmanın örneklemini oluşturmuştur. $\mathrm{Bu}$ çalışmada toplam katılim oran $1 \% 87,27$ 'dir.

\section{Verilerin Toplanması}

Çalışmaya başlamadan önce, tüm hemşireler, araştırmacılar tarafından, çalışmanın amacına ve metotlarına ilişkin bilgilendirilmiştir. Bilgilendirme sonrası anket formlarının uygulanması konusunda sözlü onamları alınmış ve sosyo demografik soruları içeren Tanıtıcı Bilgi Formu, Yoğun Bakım Hemşirelerinin Yaşadıkları Etik Sorunlar Formu ve Algılanan Stres 
Ölçeği (ASÖ) hemşireler tarafindan doldurulmuştur. Veriler araştırmacı tarafından yüz yüze görüşme yöntemiyle toplanmıştır.

\section{Veri Toplama Araçları}

Tanıtıcı Bilgi Formu: Araştırmacılar tarafından literatür (12-14) desteği ile hazırlanan bu form, hemşirelerin cinsiyet, yaş, medeni durum, eğitim durumu, çalışılan kurum, çalışılan yoğun bakım ünitesi, çalışılan pozisyon, çalışma şekli, nöbet sıklığı, günde ortalama kaç hasta yattığı, meslekte toplam çalışma yılı, yoğun bakım ünitesinde toplam çalışma yılı, günde ortalama kaç hastaya bakım verdiği ve etik eğitimi alıp almadığını içeren toplam 14 sorudan oluşmaktadır.

Yoğun Bakım Hemşirelerinin Yaşadıkları Etik Sorunlar Formu: $\mathrm{Bu}$ çalışmada yoğun bakım hemşirelerinin karşılaştıkları etik sorunlar için literatür $(8,15,16)$ taraması yapılmış olup, bu doğrultuda Gezer (15) tarafından oluşturulan etik sorunlar formu kullanılmıştır. $\mathrm{Bu}$ formda yoğun bakım ünitelerinde karşılaşılması olası tıp etiği açısından sorunlu 15 etik sorun yer almaktadır. Bu formda hemşirelerden bu etik sorunlarla meslek yaşamları sürecinde karşılaşma durumlarını evet veya hayır şeklinde belirtmeleri istenmiştir. Ayrıca bu formda hemşirelerin bu 15 etik sorunu önemseme derecelerine göre 0-10 arasında puanlandırmaları istenmiştir.

Algılanan Stres Ölçeği: Algılanan Stres Ölçeği (ASÖ) Cohen, Kamarck ve Mermelstein (17) tarafindan geliştirilmiştir. Ülkemizde geçerlik ve güvenirlik çalışması ise Eskin ve ark. (18) tarafindan 2013 yılında yapılmıştır. Toplam 10 maddeden oluşan ASÖ kişinin hayatındaki birtakım durumların ne derece stresli algılandığını ölçmek için tasarlanmıştır. Katılımcılar her maddeyi "hiçbir zaman (0)" ile "Çok sık (4)" arasında değişen 5'li Likert tipi ölçek üzerinde değerlendirmektedir. Maddelerden olumlu ifade içeren 7 madde tersten puanlanmaktadır. ASÖ'nün puanları 0 ile 40 arasında değişmektedir. Yüksek puan kişinin stres algısının fazlalığına işaret etmektedir. Eskin ve ark. (18) ölçeğin iç tutarlılığını 0,82 olarak saptamışlardır. Bu çalışmada ise ölçeğin iç tutarlılığı 0,62 olarak bulunmuştur.

\section{Araştırmanın Etik Boyutu}

Çalışmanın yürütülebilmesi için Fırat Üniversitesi Bilimsel Etik Kurulundan (15.06.2017/207128) ve çalışmanın yapıldığı kurumdan yazılı izin alınmıştır. Araştırma kapsamına alınan hemşirelere araştırmanın amac1, uygulama yöntemi ve elde edilmesi planlanan sonuçlar hakkında gerekli açıklamalar yapıldıktan sonra katılımları için sözel izinleri alınmıştır.

\section{İstatistiksel Analiz}

Veriler SPSS (Statistical Package for Social Sciences) paket programı kullanılarak analiz edilmiştir. Çalışmadaki verilerin tanımlayıcı istatistikleri ve frekans dağılımları hesaplanmıştır. Verilerin normallik varsayım kontrolü Kolmogorov-Smirnov ve Shapiro-Wilk testleri ile yapılmıştır. Verilerin bağımsız grup karşılaştırmalarında Mann-Whitney U testi kullanılmıştır. Anlamlılık düzeyi olarak 0,05 değeri alınmıştır. Ayrıca ölçeğin Cronbach alfa katsayısı hesaplanmıştır.

\section{BULGULAR}

Hemşirelerin yaş ortalaması 29,06 $\pm 4,02$ (min:21maks:38), YBÜ'nde çalışma yılı ortalaması 4,39 $\pm 3,48$, \%65,3'ü kadın ve \%91'i lisans mezunudur. Hemşirelerin $\% 86,1$ 'i etik ile ilgili eğitim aldığını ve çoğunluğu $(\% 87,9)$ bu eğitimi mezun oldukları okullarında aldıklarını belirtmişlerdir (Tablo 1).

Tablo 1. Hemşirelerin tanıtıcı bilgileri $(n=144)$

\begin{tabular}{|c|c|c|c|}
\hline \multicolumn{2}{|l|}{ Tanitıcı bilgiler } & n & $\%$ \\
\hline \multicolumn{2}{|l|}{ Yaș $(\bar{X} \pm S S)$} & \multicolumn{2}{|c|}{$29,06 \pm 4,02$} \\
\hline \multicolumn{2}{|c|}{ YB ̈̈̈ çalıșma yılı ( $\overline{\mathrm{X}} \pm S S)$} & \multicolumn{2}{|c|}{$4,39 \pm 3,48$} \\
\hline \multirow[t]{2}{*}{ Cinsiyet } & Kadın & 94 & 65,3 \\
\hline & Erkek & 50 & 34,7 \\
\hline \multirow{2}{*}{ Medeni durum } & Evli & 80 & 55,6 \\
\hline & Bekâr & 64 & 44,4 \\
\hline \multirow{5}{*}{ Eğitim durumu } & Sağlık meslek & & \\
\hline & lisesi & 5 & 3,5 \\
\hline & Ön lisans & 1 & 0,7 \\
\hline & Lisans & 131 & 91,0 \\
\hline & Lisansüstü & 7 & 4,9 \\
\hline \multirow{4}{*}{ Çalıştığı YBÜ } & $\begin{array}{l}\text { Dahili Bilimler } \\
\text { YRÏI }\end{array}$ & 60 & 417 \\
\hline & $\begin{array}{l}\text { YBU } \\
\text { Cerrahi Bilimler }\end{array}$ & 60 & 41,7 \\
\hline & YBÜ & 53 & 36,8 \\
\hline & Pediatri YBÜ & 31 & 21,5 \\
\hline \multirow{2}{*}{ Çalışma statüsü } & Sorumlu hemşire & 4 & 2,8 \\
\hline & Servis hemşiresi & 140 & 97,2 \\
\hline \multirow{5}{*}{ Çalışma yılı } & 1 yil ve alt1 & 17 & 11,8 \\
\hline & 2-6 y1l & 71 & 49,3 \\
\hline & 7-11 y1l & 38 & 26,4 \\
\hline & $12-16$ y1l & 16 & 11,1 \\
\hline & 17 yil ve üzeri & 2 & 1,4 \\
\hline \multirow{3}{*}{ Çalışma şekli } & Vardiyalı & 39 & 27,1 \\
\hline & Gündüz & 20 & 13,9 \\
\hline & Nöbet & 85 & 59,0 \\
\hline \multirow{2}{*}{ Etik eğitimi alma } & Evet & 124 & 86,1 \\
\hline & Hayır & 20 & 13,9 \\
\hline \multirow{3}{*}{$\begin{array}{l}\text { Etik eğitiminin } \\
\text { alındığı yer } \\
(n=124)\end{array}$} & Okul Eğitimi & 109 & 87,9 \\
\hline & Kurs & 6 & 4,8 \\
\hline & $\begin{array}{l}\text { Toplantı } \\
\text { Katılımı }\end{array}$ & 9 & 7.3 \\
\hline
\end{tabular}

X: Ortalama; SS: Standart Sapma; YBÜ: Yoğun Bakım Ünitesi

Karşılaşılan etik sorunlar içerisinde en yüksek oranın sırasıyla; "Mesleki hiyerarşide alt basamaklarda yer alanlara fazla iş yüklenmesi" (\%91), "Hekim tarafindan yerine getirilmesi gereken uygulamaların hemşirelere devredilmesi” (\%90,3), "Durumu daha kritik olan hastalara yer açmak için stabil hastaların servislere çıkarılması" (\%80,6) ve "Hastaya beyin ölümü tanısı konulması ve durumun aileye bildirilmesi" (\%80,6) olduğu belirlenmiştir (Tablo 2).

Hemşireler tarafindan en yüksek önemseme ortalamasına sahip olan etik sorunların ise sirasıyla; "Mesleki hiyerarşide alt basamaklarda yer alanlara fazla iş

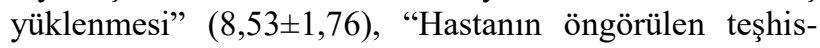
tedavi işlemleri hakkında bilgilendirilememesi veya onayının alınamaması" $(8,47 \pm 4,16)$, "Hekim tarafindan yerine getirilmesi gereken uygulamaların hemşirelere devredilmesi” $(8,28 \pm 2,09)$, ve "Beyin ölümü gerçekleşen 
Tablo 2. Yoğun bakım hemşirelerinin karşılaştıkları etik sorunlar ve önemsemeye yönelik puan ortalamaları

\begin{tabular}{|c|c|c|c|c|}
\hline \multirow[b]{2}{*}{ Etik sorunlar } & \multicolumn{2}{|c|}{ Karşılaşan } & \multicolumn{2}{|c|}{ Karşılaşmayan } \\
\hline & n (\%) & $\begin{array}{c}\text { Önemseme } \\
(\bar{X} \pm \text { SS })\end{array}$ & n (\%) & $\begin{array}{c}\text { Önemseme } \\
(\bar{X} \pm S S)\end{array}$ \\
\hline $\begin{array}{l}\text { 1. Hasta veya hasta yakınlarının ötanazi } \\
\text { talebinde bulunması }\end{array}$ & $29(20,1)$ & $7,10 \pm 2,92$ & $115(79,9)$ & $4,20 \pm 2,22$ \\
\hline $\begin{array}{ll}2 . & \text { Hasta hakkında resüsite edilmeme kararının } \\
\text { (DNR order) verilmesi }\end{array}$ & $58(40,3)$ & $6,75 \pm 2,49$ & $86(59,7)$ & $5,08 \pm 2,66$ \\
\hline $\begin{array}{l}\text { 3. İyileşme olasılığı kalmayan hastanın } \\
\text { solunum desteğinin kesilmesi (ventilatörden } \\
\text { ayrılması). }\end{array}$ & $21(14,6)$ & $7,43 \pm 2,22$ & $123(85,4)$ & $4,61 \pm 2,80$ \\
\hline $\begin{array}{l}\text { 4. Solunum desteğinin, ihtiyaç duyan birden } \\
\text { fazla hastadan hangisine verileceğini } \\
\text { kararlaştırma }\end{array}$ & $33(22,9)$ & $7,48 \pm 2,28$ & $111(77,1)$ & $5,57 \pm 2,86$ \\
\hline \begin{tabular}{|l} 
5. Hastaya beyin ölümü tanısı konulması ve \\
durumun aileye bildirilmesi
\end{tabular} & $116(80,6)$ & $8,03 \pm 2,04$ & $28(19,4)$ & $6,31 \pm 2,86$ \\
\hline $\begin{array}{ll}\text { 6. } & \text { Beyin ölümü gerçekleşen hastanın } \\
\text { organlarını bağışlama konusunun ailesiyle } \\
\text { görüşülmesi }\end{array}$ & $88(61,1)$ & $8,23 \pm 1,94$ & $56(38,9)$ & $6,90 \pm 2,74$ \\
\hline \begin{tabular}{|l} 
7. \\
$\begin{array}{l}\text { Hastanın öngörülen teşhis-tedavi işlemleri } \\
\text { hakkında bilgilendirilememesi veya onayının } \\
\text { alınamaması }\end{array}$
\end{tabular} & $64(44,4)$ & $8,47 \pm 4,16$ & $80(55,6)$ & $5,26 \pm 2,62$ \\
\hline \begin{tabular}{|ll}
8. & Hastanın öngörülen teşhis-tedavi \\
& işlemlerinden bazılarını reddetmesi
\end{tabular} & $108(75,0)$ & $7,16 \pm 3,03$ & $36(25,0)$ & $5,29 \pm 2,40$ \\
\hline $\begin{array}{l}\text { 9. Hastanın hayati tehlike bulunmasına rağmen } \\
\text { taburcu edilmeyi istemesi }\end{array}$ & $103(71,5)$ & $8,09 \pm 2,05$ & $41(28,5)$ & $5,58 \pm 2,60$ \\
\hline $\begin{array}{l}\text { 10. Hasta yakınlarının kötü prognozun hastadan } \\
\text { gizlenmesini istemesi }\end{array}$ & $100(69,4)$ & $7,68 \pm 2,08$ & $44(30,6)$ & $5,74 \pm 2,46$ \\
\hline $\begin{array}{l}\text { 11. Durumu daha kritik olan hastalara yer açmak } \\
\text { için stabil hastaların servislere çıkarılması }\end{array}$ & $116(80,6)$ & $6,25 \pm 2,36$ & $28(19,4)$ & $5,88 \pm 2,70$ \\
\hline $\begin{array}{l}\text { 12. Yoğun bakım hekimi ile konsültasyona gelen } \\
\text { hekim arasında mesleki görüş ayrılığı } \\
\text { yaşanması }\end{array}$ & $94(65,3)$ & $7,20 \pm 2,26$ & $50(34,7)$ & $5,64 \pm 2,78$ \\
\hline $\begin{array}{l}\text { 13. Hekim tarafindan yerine getirilmesi gereken } \\
\text { uygulamaların hemşirelere devredilmesi }\end{array}$ & $130(90,3)$ & $8,28 \pm 2,09$ & $14(9,7)$ & $6,97 \pm 2,77$ \\
\hline $\begin{array}{l}\text { 14. Hastalar arasında ziyaretçi ve refakatçi } \\
\text { kabulünde adil yaklaşımın olmaması }\end{array}$ & $105(72,9)$ & $7,41 \pm 2,13$ & $39(27,1)$ & $6,05 \pm 2,73$ \\
\hline $\begin{array}{l}\text { 15. Mesleki hiyerarşide alt basamaklarda yer } \\
\text { alanlara fazla iş yüklenmesi }\end{array}$ & $131(91,0)$ & $8,53 \pm 1,76$ & $13(9,0)$ & $7,22 \pm 2,85$ \\
\hline
\end{tabular}

$\overline{\mathrm{X}}$ : Ortalama; SS: Standart Sapma

hastanın organlarını bağışlama konusunun ailesiyle görüşülmesi” $(8,23 \pm 1,94)$ olduğu saptanmıştır (Tablo 2$)$.

Hemşirelerin algılanan stres ölçeği puan ortalaması $22,38 \pm 4,52$ olarak bulunmuş olup, tüm etik sorunlar için orta düzeyde stres algıladıkları saptanmıştır. Etik sorunla karşılaşan hemşirelerle karşılaşmayan hemşirelerin algıladıkları stres düzeylerinin benzer olduğu, sadece "Hekim tarafindan yerine getirilmesi gereken uygulamaların hemşirelere devredilmesi” etik sorunu ile karşılaşanların karşılaşmayanlara göre algılanan stres düzeylerinin daha yüksek olduğu saptanmıştır $(\mathrm{p}<0,05$, Tablo 3).

\section{TARTIŞMA}

Araştırmanın örneklemini oluşturan yoğun bakım hemşirelerinin çoğunluğunun lisans mezunu olduğu (\%91), etik ile ilgili eğitim aldıkları $(\% 86,1)$ ve bu eğitimi alanların da büyük çoğunluğunun etik konusundaki bilgileri mezuniyet öncesi okul eğitimi $(\% 87,9)$ sırasında kazandığı saptanmıştır (Tablo 1). Başak ve arkadaşları (1) yapmış oldukları çalışmada hemşirelerin \%78,9'u, Yönt ve arkadaşlarının (8) çalışmasında hemşirelerin \%85,2'si, Gezer (15) yapmış olduğu çalışmada hemşirelerin \%62'si ve Dikmen (6) yapmış olduğu çalışmada hemşirelerin \%78'inin hemşirelik eğitimi sırasında etiğe ilişkin bilgi kazandıkları belirlenmiştir. $\mathrm{Bu}$ bulgular, hemşirelerin yarısından fazlasının etik eğitimi konusundaki bilgilerini hemşirelik eğitimi ile kazandıklarını göstermektedir. Etik sorunları çözme becerisinin kazanılmasında ve etik davranışların geliştirilebilmesinde etik konusunda verilecek eğitimin önemli bir faktör olduğu belirtilmektedir (19). Etik karar verebilme, sağlık alanında ortaya çıkan etik sorunların farkında olunması ve etik sorunlara yönelik profesyonel bir yaklaşım sergilenebilmesi bakımından önemlidir (20). Etik eğitimi hemşirelere karar verme becerilerini geliştirip çağdaş hemşirelik uygulamalarını gerçekleştirmede kolaylaştırıcı bir etki sağlayıp analitik düşünce yapısını geliştirerek sistematik yaklaşımı kolaylaştıracaktır (21). Özellikle etik sorunların sık yaşandığı klinik ortamlar olarak belirtilen yoğun bakım ünitelerinde çalışan hemşirelerin etik sorunları tanıması ve doğru kararlar alması için etik ile ilgili eğitim son derece önemlidir. Yoğun bakım hastalarının sağlık sorunlarının özelliği, teknoloji destekli hizmet sunumu, acil kararlar verme ve acil müdahalede 
Tablo 3. Yoğun bakım hemşirelerinde etik sorunların stres düzeylerine etkileri

\begin{tabular}{|c|c|c|c|c|}
\hline \multirow[b]{2}{*}{ Etik sorunlar } & \multicolumn{2}{|c|}{ Algılanan Stres Ölçeği Puanı } & \multirow[b]{2}{*}{$\mathbf{U}^{*}$} & \multirow[b]{2}{*}{$\mathbf{p}$} \\
\hline & $\begin{array}{l}\text { Etik Sorunla } \\
\text { Karşılaşan } \\
\text { Sira Ort. } \\
\end{array}$ & $\begin{array}{c}\text { Etik Sorunla } \\
\text { Karşılaşmayan } \\
\text { Sıra Ort. } \\
\end{array}$ & & \\
\hline $\begin{array}{l}\text { 1. Hasta veya hasta yakınlarının ötanazi } \\
\text { talebinde bulunması }\end{array}$ & 61,22 & 75,34 & 1340,50 & 0,102 \\
\hline $\begin{array}{l}\text { 2. Hasta hakkında resüsite edilmeme } \\
\text { kararının (DNR order) verilmesi }\end{array}$ & 76,62 & 69,72 & 2255,00 & 0,328 \\
\hline $\begin{array}{l}\text { 3. İyileşme olasılığı kalmayan hastanın } \\
\text { solunum desteğinin kesilmesi } \\
\text { (ventilatörden ayrılması). }\end{array}$ & 58,67 & 74,86 & 1001,00 & 0,099 \\
\hline $\begin{array}{l}\text { 4. Solunum desteğinin, ihtiyaç duyan birden } \\
\text { fazla hastadan hangisine verileceğini } \\
\text { kararlaştırma }\end{array}$ & 67,83 & 73,89 & 1677,50 & 0,462 \\
\hline $\begin{array}{l}\text { 5. Hastaya beyin ölümü tanısı konulması ve } \\
\text { durumun aileye bildirilmesi }\end{array}$ & 73,14 & 69,84 & 1549,50 & 0,706 \\
\hline $\begin{array}{l}\text { 6. } \begin{array}{l}\text { Beyin ölümü gerçekleşen hastanın } \\
\text { organlarını bağışlama konusunun ailesiyle } \\
\text { görüşülmesi }\end{array} \\
\end{array}$ & 68,10 & 79,41 & 2077,00 & 0,111 \\
\hline $\begin{array}{l}\text { 7. Hastanın öngörülen teşhis-tedavi işlemleri } \\
\text { hakkında bilgilendirilememesi veya } \\
\text { onayının alınamaması. }\end{array}$ & 74,34 & 71,03 & 2442,00 & 0,634 \\
\hline $\begin{array}{l}\text { 8. Hastanın öngörülen teşhis-tedavi } \\
\text { işlemlerinden bazılarını reddetmesi }\end{array}$ & 72,64 & 72,08 & 1929,00 & 0,945 \\
\hline $\begin{array}{l}\text { 9. Hastanın hayati tehlike bulunmasına } \\
\text { rağmen taburcu edilmeyi istemesi }\end{array}$ & 72,03 & 73,68 & 2063,00 & 0,829 \\
\hline $\begin{array}{l}\text { 10. Hasta yakınlarının kötü prognozun } \\
\text { hastadan gizlenmesini istemesi }\end{array}$ & 74,81 & 67,25 & 1969,00 & 0,315 \\
\hline $\begin{array}{l}\text { 11. Durumu daha kritik olan hastalara yer } \\
\text { açmak için stabil hastaların servislere } \\
\text { çıarılması }\end{array}$ & 74,59 & 63,84 & 1381,50 & 0,219 \\
\hline $\begin{array}{l}\text { 12. Yoğun bakım hekimi ile konsültasyona } \\
\text { gelen hekim arasında mesleki görüş } \\
\text { ayrılığı yaşanması }\end{array}$ & 71,56 & 74,26 & 2262,00 & 0,711 \\
\hline $\begin{array}{l}\text { 13. Hekim tarafından yerine getirilmesi } \\
\text { gereken uygulamaların hemşirelere } \\
\text { devredilmesi }\end{array}$ & 74,96 & 49,64 & 590,00 & 0,030 \\
\hline $\begin{array}{l}\text { 14. Hastalar arasında ziyaretçi ve refakatçi } \\
\text { kabulünde adil yaklaşımın olmaması }\end{array}$ & 74,33 & 67,58 & 1855,50 & 0,386 \\
\hline $\begin{array}{l}\text { 15. Mesleki hiyerarşide alt basamaklarda yer } \\
\text { alanlara fazla iş yüklenmesi }\end{array}$ & 73,83 & 59,12 & 677,50 & 0,223 \\
\hline
\end{tabular}

*: Mann-Whitney U testi; Sira Ort.: Sira Ortalaması

bulunma gibi nedenlerle yoğun bakım ünitelerinde etik sorunlarla sık karşılaşılmaktadır (4). Bu ortamlarda çalışan hemşireler de etik sorunlarla sık karşılaşabilmekte ve etik kararlar vermek durumunda kalabilmektedir (8). Bizim araştırmamızda hemşirelerin çoğunluğunun etik sorunlar formunda belirtilen tüm etik sorunlarla karşılaştıkları saptanmıştır. Kabukcu, Özgök ve Babacan'ın (22) çalışmasında yoğun bakımdaki hemşirelerin \%43'ünün etik sorun yaşadıkları, yalnızca 1/5'nin bu sorunları çözebildiği ifade edilmiştir. Başak ve arkadaşları (1) yapmış oldukları çalışmada da hemşirelerin \%46,7'sinin yoğun bakımda çalıştıkları süre boyunca etik sorun yaşadıklarını, etik sorun yaşayanların \%35,7'sinin ise, yaşadıkları etik sorunu çözemediklerini ifade etmişlerdir. Yine Dikmen (6) yapmış olduğu çalışmada hemşirelerin \%74'ü yoğun bakımda çalıştıkları süre boyunca etik sorunlar yaşadıklarını, etik sorunlar yaşayanların \%62'si ise, yaşadıkları etik sorunu çözemediklerini ifade ettiklerini belirtmektedir.

Araştırmamızda "Mesleki hiyerarşide alt basamaklarda yer alanlara fazla iş yüklenmesi" ve "Hekim tarafindan yerine getirilmesi gereken uygulamaların hemşirelere devredilmesi" en sık karşılaşılan etik sorunlar olarak bulunmuştur. Gezer (15) yaptığı çalışmada da hemşirelerin en sık karşılaştıkları etik sorunların "Durumu daha kritik olanlara yer açmak için stabil hastaların servislere çıkartılması" (\%97) ve "Hekim tarafindan yerine getirilmesi gereken uygulamaların hemşirelere devredilmesi” (\%88) olarak saptamıştır. Yönt ve arkadaşları (8) çalışmalarında; hemşirelerin en fazla yaşadıkları etik sorunlardan birinin "Doktorun görevi olan işlemleri-girişimleri yapmak zorunda kalıyorum" şeklinde ifade ettikleri etik sorun olduğu görülmüştür. Yine aynı çalışmada; hastanın tedavisi ve bakımına ilişkin hekim ve hemşire iletişiminden doğan etik 
sorunların sık yaşanan etik sorun olduğu belirtilmiştir (8). Bir başka çalışmada da; hemşirelerin \%14'ünün tedavi sırasında hekim-hemşire ilişkilerine bağlı etik sorunlar yaşadıkları saptanmıştır (23). Çobanoğlu ve Algıer'in (24) çalışmasında da, hemşirelerin hekimlerle hiyerarşik sorunlar nedeniyle çatışma yaşadıkları belirtilmiştir. Park ve arkadaşları (25), yoğun bakım ünitesinde çalışan hemşirelerden elde ettikleri verilere göre, yoğun bakım ünitelerinde yaşanan etik sorunların en önemlisinin; sağllk profesyonellerinin ve ailenin uygun olmayan davranışları ile ilgili sorunlar ve iletişimsizlik olduğunu saptamıştır.

Yoğun bakım ünitelerinde hemşire ve sağlık personelinin azlığı, yoğun bakım yatak sayısının yetersizliği gibi nedenler yoğun bakım ünitelerinde hasta triaj1 yapılmasına yol açmaktadır (4). Araştırmamıza göre "Durumu daha kritik olan hastalara yer açmak için stabil hastaların servislere çıkarılması" ve "Hastaya beyin ölümü tanısı konulması ve durumun aileye bildirilmesi” yoğun bakım hemşirelerinin en sık karşılaştıkları diğer etik sorunlar olarak bulunmuştur. Oerlemans ve arkadaşları (26) da yoğun bakım ünitelerinde hekim ve hemşirelerle yaptıkları çalışmalarında; karşılaşılan etik sorunların tedavi kararlarından ve yatakların dolu olması nedeni ile hastaların tedavileri bitmeden taburcu edilmesinden kaynaklandığını saptamıştır. Ayrıca teknolojik ve farmakolojik girişimlerle yaşamı desteklemenin, hasta bireyin bulgularının azaltılmasına ya da iyileşmesine katkıda bulunmadığına karar vermek sağl1k profesyonelleri için en güç kararlardan biridir (4). Çobanoğlu ve Algier (24) tarafından yoğun bakım ünitelerinde yapılan çalışmada, hekim ve hemşireler için yaşam sonuna ilişkin kararların en temel etik sorun olduğu saptanmıştır. Park ve arkadaşları (7) yoğun bakım ünitelerinde en sık karşılaşılan etik sorunların; yaşam sonu tedavi sorunları, bakım sorunları ve insan hakları sorunları olduğunu saptamıştır. Voigt ve arkadaşları (27) çalışmalarında, yoğun bakım ünitelerinde en çok görülen etik sorunlar içerisinde hasta veya ailesinin sağlık profesyonelleri arasındaki yaşam sonu bakım ile ilgili anlaşmazlıklar olduğu belirtmektedirler.

Yoğun bakım ünitelerinde çalışan sağlık profesyonelleri alternatifler arasından bir seçim yapma durumuyla sıklıkla karşılaşmaktadır. Eşit etkiye/yarara sahip görünen iki seçenekten birine karar vermek zorunda kalmak etik ikilemlerin ve çatışmaların ortaya çıkmasına neden olmaktadır (4). Breen ve arkadaşları (28) yoğun bakım hastaları hakkında karar verme konusunda sağlık profesyonellerinin büyük bir kısmının etik ikilem yaşadıklarını belirtmişlerdir. Sağlık personelinin yasal olarak doğru, ahlaksal olarak yanlış bir uygulama ile karşılaştığında moral distress yaşadıkları belirtilmektedir (29). YBÜ'lerinin hastanelerde çoğunlukla en stresli yerler olduğu ve yaşamı tehdit eden akut hastalığa sahip hastaların genel sağlığını ve organ fonksiyonlarını yeniden düzenlemek için ünite çalışanlarının sık sık hızla ardışık çoklu tedavi kararları almak zorunda kalması da çalışanların daha fazla stres yaşamalarına neden olabilmektedir. Bizim araştırmamızda da hemşirelerin belirtilen tüm etik sorunlar nedeniyle orta düzeyde stres algıladıkları saptanmıştır. Ayrıca çalışmamızda sadece "Hekim tarafindan yerine getirilmesi gereken uygulamaların hemşirelere devredilmesi" etik sorunu ile karşılaşanların karşılaşmayanlara göre algılanan stres düzeylerinin daha yüksek olduğu saptanmıştır. Yoğun bakım ünitelerinde yaşanan etik ikilemlerin yanı sıra primer karar vericinin hekim olması, yoğun bakım hemşirelerinin karar verme sürecine katılımlarının sınırlı olması gibi nedenler de hemşirelerin stres yaşamalarına neden olmaktadır (30-32). Aynı zamanda etik sorunların farklı algılanması yanlış anlaşılma ve çatışmalara da yol açmakta ve bu durum ekip üyelerinde stres ve anksiyeteye yol açmaktadır (31). Hemşirelerin yoğun bakım ünitelerinde ortaya çıkabilecek etik sorunlar ve olası nedenleri hakkında yeterli bilgiye ve etik duyarlılığa sahip olmalarının etik sorunların ve böylelikle yaşanabilecek stres faktörlerinin önlenmesinde önemli olduğunu söyleyebiliriz.

\section{SONUÇ VE ÖNERİLER}

Çalışmada yoğun bakım hemşirelerinin en çok karşılaştıkları etik sorunların; "Mesleki hiyerarşide alt basamaklarda yer alanlara fazla iş yüklenmesi", "Hekim tarafindan yerine getirilmesi gereken uygulamaların hemşirelere devredilmesi" ve "Durumu daha kritik olan hastalara yer açmak için stabil hastaların servislere çıkarılması" olduğu saptanmıştır. Hemşirelerinin karşılaştıkları bu etik sorunlar içerisinde en fazla önemsediklerinin "Mesleki hiyerarşide alt basamaklarda yer alanlara fazla iş yüklenmesi" ve "Hastanın öngörülen teşhis-tedavi işlemleri hakkında bilgilendirilememesi veya onayının alınamaması" olduğu görülmüş olup etik sorunların hemşirelerde orta düzeyde stres algısına yol açtığ 1 bulunmuştur.

Sürekli değişim ve gelişimin olduğu yoğun bakım ünitelerinde çalışan sağlık profesyonellerinin mesleki yeterlilikleri, temel etik ilkeler ve yasal düzenlemeler konusunda bilinçli olmaları, ekip çalışması anlayışının benimsenmiş olması etik sorunların önlenmesine ve etkin çözümlerin oluşturulmasına katkı sağlayacaktır. Etik ile ilgili hizmet içi eğitimler, seminerler ve yapılacak bilgilendirme toplantıları düzenlenerek etik sorunların ve beraberinde algılanan stres düzeyinin azaltılması yönünde önlemler alınmalıdır. Bunun yanı sıra hemşirelerin uygulamalarda kararlara daha fazla katılımlarının sağlanması etik sorunların neden olduğu stresin azaltılmasına olumlu katkıda bulunabilir. İleriki çalışmalarda bu araştırmanın geçerliliğini test etmek için daha büyük örneklemlerde tekrarlanması ve hemşirelerin karşılaştıkları etik sorunların neler olduğu ve stres düzeylerini ne kadar etkilediğinin daha iyi anlaşılmasına yardımcı olacak nitel çalışmaların yürütülmesi önerilmektedir.

\section{TEŞEKKÜR}

Araştırmaya katılan tüm yoğun bakım ünitesinde çalışan hemşirelere katkılarından dolayı teşekkür ederiz.

\section{KAYNAKLAR}

1. Başak T, Uzun Ş, Arslan F. Yoğun bakım hemşirelerinin etik duyarlılıklarının incelenmesi. Gülhane Tıp Dergisi. 2010; 52(2): 76-81.

2. Kırşan M, Yıldırım D, Ceylan B, Korhan EA, Uyar M. Yoğun bakım ünitelerinde etik sorunlar: sistematik derleme. Turkiye Klinikleri J Med Ethics. 2018; 26(2): 57-65. 
3. İbrahimoğlu Ö. Son dönem yoğun bakım hastalarının bakımında etik sorunlar ve etik yaklașım. Sağlık Akademisyenleri Dergisi. 2017; 4(3): 216-20.

4. Tel H. Yoğun bakım ünitelerinde sık karşılaşılan etik sorunlar. Cumhuriyet Hemşirelik Dergisi. 2012; 1(1): 30-8.

5. Eşer S, Khorshid L, Demir Y. Yoğun bakım hemşirelerinde eleştirel düşünme eğilimi ve etkileyen faktörlerin incelenmesi. Cumhuriyet Üniversitesi Hemşirelik Yüksekokulu Dergisi. 2007; 11(3): 13-22.

6. Dikmen Y. Yoğun bakım hemşirelerinde etik duyarlılığın incelenmesi. Cumhuriyet Hemşirelik Dergisi. 2013; 2(1): 1-7.

7. Park M, Jeon SH, Hong HJ, Cho SH. A Comparison of ethical issues in nursing practice across nursing units. Nurs Ethics. 2014; 21(5): 594-607.

8. Yönt GH, Korhan EA, Dizer B, Koyuncu R. Hemşirelerin yoğun bakım ünitelerinde yaşadıkları etik sorunların belirlenmesi. Turkiye Klinikleri Journal of Medical Ethics. 2013; 21(2): 74-8.

9. Öztürk H, Hindistan S, Kasım S, Candaş B. Yoğun bakım ünitelerinde hekim ve hemşirelerin etik duyarlılığı. Yoğun Bakım Hemşireliği Dergisi. 2009; 13(2): 77-84.

10. Altınöz Ü, Demir S. Yoğun bakımda çalışan hemşirelerde çalışma ortamı algısı, psikolojik distres ve etkileyen faktörler. Psikiyatri Hemşireliği Dergisi Journal of Psychiatric Nursing. 2017; 8(2): 95-101.

11. Moon YJ, Kim O. Ethics in the intensive care unit. Tuberc Respir Dis. 2015; 78(3): 175-9.

12. Cerit B. Hemşirelerin profesyonellik davranışları ile etik karar verebilme düzeyi arasındaki ilişkinin incelenmesi [Doktora Tezi]. Ankara: Hacettepe Üniversitesi Sağlık Bilimleri Enstitüsü; 2010.

13. Gül Ş, Aşiret GD, Kahraman BB, Devrez N, Büken NÖ. Etik dersi alan ve almayan hemşirelik öğrencilerinin etik karar verebilme düzeylerinin incelenmesi. Hemşirelikte Araştırma Geliştirme Dergisi. 2013; 15(1): 23-31.

14. Şen H, Yılmaz F, Özcan D, Bahçeci N. Kamu hastanelerinde görev yapan başhekim ve başhemşirelerin duygusal zeka düzeyleri ile etik muhakeme yetenekleri ve etkileyen faktörler. Hemşirelikte Eğitim ve Araştırma Dergisi. 2013; 10(3): 18-26.

15. Gezer DŞ. Yoğun bakım hemşirelerinin yaşadıkları etik sorunlar konusunda Adana ölçeğinde bir araştırma [Yüksek Lisans Tezi]. Adana: Çukurova Üniversitesi Sağlık Bilimleri Enstitüsü Tıp Tarihi ve Etik Anabilim Dalı; 2010.

16. Tosun H. Sağlık bakımı uygulamalarında deneyimlenen etik ikilemlere karşı hekim ve hemşirelerin duyarlılıklarının belirlenmesi [Doktora Tezi]. İstanbul: İstanbul Üniversitesi Sağlık Bilimleri Enstitüsü Hemşirelik Esasları Anabilim Dalı; 2005.

17. Cohen S, Kamarck T, Mermelstein R. A global measure of perceived stress. Journal of Health and Social Behavior. 1983; 24(4): 385-96.

18. Eskin M, Harlak H, Demirkıran F, Dereboy Ç. Algılanan stres ölçeğinin Türkçeye uyarlanması: güvenirlik ve geçerlik analizi. Yeni Symposium. 2013; 51(3): 132-40.

19. Aybek B. Karataş T. Öğretmen adaylarının etik ve mesleki etik hakkındaki görüşlerinin incelenmesi. Eğitim ve Öğretim Araştırmaları Dergisi. 2016; 5(Özel Say1): 96-108.

20. Burkhardt MA, Nathaniel AK. Çağdaş hemşirelikte etik. Alpar ŞE, Bahçecik N, Karabacak Ü, çeviri editörleri. İstanbul Medikal Yayıncılık; İstanbul. 2013.

21. Özlem M. Etik eğitim programının hemşirelerin etik karar verebilme düzeyine etkisi [Yüksek Lisans Tezi]. İzmir: Katip Çelebi Üniversitesi Sağlık Bilimleri Enstitüsü Hemşirelik Anabilim Dalı; 2016.

22. Kabukcu N, Özgök Y, Babacan B. Yoğun bakım hemşirelerinin etik duyarlılığı. 4. Ulusal Yoğun Bakım Hemşireliği Kongresi Özet Kitab1; 15-17 Nisan 2010; Trabzon. s.73.

23. Gjerberg E, Forde R, Pedersen R, Bollig G. Ethical challenges in the provision of end-of-life care in Norwegian nursing homes. Social Science \& Medicine. 2010; 71(4): 677-84.

24. Çobanoğlu N, Algıer L. A qualitative analysis of ethical problems experienced by physicians and nurses in intensive care units in Turkey. Nursing Ethics. 2004; 11(5): 444-58.

25. Park DW, Moon JY, Ku EY, Kim SJ, Koo YM, Kim OJ, et al. Ethical issues recognized by critical care nurses in the intensive care units of a tertiary hospital during two separate periods. J Korean Med Sci. 2015; 30(4): 495-501.

26. Oerlemans AJ, Van Sluisveld N, Van Leeuwen ES, Wollersheim H, Dekkers WJ, Zegers M. Ethical problems in intensive care unit admission and discharge decisions: a qualitative study among physicians and nurses in the Netherlands. BioMed Central Medical Ethics. 2015; 16(1): 16-9.

27. Voigt LP, Rajendram P, Shuman AG, Kamat S, McCabe MS, Kostelecky N, et al. Characteristics and outcomes of ethics consultations in an oncologic intensive care unit. Journal of Intensive Care Medicine. 2015; 30(7): 436-42.

28. Breen CM, Abernethy AP, Abbott KH, Tulsky JA. Conflict associated with decisions to limit lifesustaining treatment in intensive care units. Society of General Internal Medicine. 2001; 16(5): 283-9.

29. Elçigil A, Bahar Z, Beşer A, Mızrak B, Bahçelioğlu D, Demirtaş D ve ark. Hemşirelerin karşılaştıkları etik ikilemlerin incelenmesi. Anadolu Hemşirelik ve Sağlık Bilimleri Dergisi. 2011; 14(2): 52-60.

30. Melia KM. Ethical issues and the importance of consensus for the intensive care team. Social Science \& Medicine. 2001; 53(6): 707-19.

31. Oberle K, Hughes D. Doctors and nurses perceptions of ethical problems in end of life decisions. Journal of Advanced Nursing. 2001; 33(6): 707-15.

32. Viney C. A phenomenological study of ethical decision-making experiences among senior intensive care nurses and doctors concerning withdrawal of treatment. Nursing in Critical Care. 1996; 1(4): 182-7. 